\title{
Free Trade Arrangement Between India and Japan: An Exploratory Analysis*
}

\author{
Kaliappa Kalirajan \\ Foundation for Advanced Studies on International Development and \\ National Graduate Institute for Policy Studies, Tokyo \\ and \\ Swapan Bhattacharya \\ National Graduate Institute for Policy Studies, Tokyo and \\ Indian Institute of Public Administration, New Delhi
}

* Comments and suggestions given by the participants at the $60^{\text {th }}$ year of Independence of India Conference organized by the Australia South Asia Research Centre at the Australian National University from 20 August to 21 August 2007. 


\section{I: Introduction}

One of the interesting events of the world economy over the past one and a half decade has been the phenomenal growth of regional trading agreements and significant increase in world trade emerging from these arrangements. Regionalism has become so widespread in the sense that at present 60 per cent of world trade is conducted among the members of the blocs. At the advent of "new regionalism", different countries have formed the complex web of regional trading agreements what Bhagwati and Panagariya (1999), and Estevadeordal (2006) among others refer to as a "spaghetti Bowl" phenomenon in the international trading system. The World Trade Organization (WTO) website informs that by July 2005, a total of 330 agreements have been concluded, of which 130 agreements were concluded prior to the inception of the WTO on 1 January 1995. Of the total regional trade agreements (RTAs) registered with the WTO, 188 are currently in force and there are 33 major reginal trading blocs (RTBs) worldwide. Asia is not lagging behind other continents as far as the formation of regional blocs is concerned. As of now, there are 49 major sub regional and bilateral trade and cooperation agreements in the Asian region. All the RTAs registered with the WTO are either based on Article XIV of WTO or Article XII of the Enabling Clause.

The basic reason for this phenomenal growth of regionalism is generally attributed to the weakening of multilateralism at the auspices of WTO right from its inception. It is almost impossible for all 151 members of WTO to come into consensus of any particular issue, which results failure of negotiations of several ministerial rounds including the last one. However, there is another important reason for the phenomenal growth of regional trading agreements, which has received less attention in the literature. This concerns the lack of focus on trade policy reforms and constraints to implementing liberalization policies effectively within concerned countries, which are otherwise called 'behind the border' constraints. As economic theory argues, liberalization of trade through policy induced measures by reducing and then eliminating tariff and non-tariff barriers promotes efficiency of allocation of resources to productive uses, exploitation of scale economies, encourages competition, increases factor productivity and increases trade flows, thereby, promoting economic growth (Barro and Sala-i-Martin, 1995 and Wacziarg, 1997). However, reality seems to be different from theoretical predictions. In spite of instituting various measures of trade liberalization in many countries, still there remain some country-specific barriers, which impede the growth of world trade (Kalirajan, 1999). For example, Elizondo and Krugman (1992) argue that trade flows are adversely affected when infrastructure development are concentrated on only some developed pockets of the country. Also, large government size (Rodrik, 1998), weak and inefficient institutions in home country (Wilson, Mann, and Otsuki, 2004 Levchenko, 2004) and political lobbying (Gawande and Krishna, 2001) have been identified to constraint trade flows between countries.

Empirical studies mentioned above show that inspite of implementing trade liberalization in developing countries, they could not reap the benefit of the liberalization fully because of country-specific trade-constraining effects of mainly institutional and infrastructural factors, which are not seriously addressed by proper reform measures. These constraints would create a "trade-gap" by reducing actual 
trade flows between countries from their potential levels. It is in this context, besides multilateral efforts, regional and bilateral efforts facilitate countries to address, particularly those non-tariff issues effectively in order to minimize the gap between actual and potential trade on the one hand and to extract the benefits of free trade on the other. This process evolves through progressive stages of trade and investment cooperation agreements among governments through several bilateral, regional and multilateral arrangements among different trading partners (Lawrence, 1996).

Recently, there has been active persuasion by both India and Japan to conclude free trade agreement between them. Though Japan has been always a promoter of multilateral agreements, of late due to the emergence of different FTAs initiated by the United States, Japan has felt an acute need for its own treaty with different countries to protect its market share in world trade. India, in the process of increasing its market share has been also keen in making FTAs within the Asian region. ${ }^{1}$ The governments of Japan and India started negotiating a comprehensive Economic Partnership Agreement in January 2007. They expect to conclude a deal in 2009. The main objectives of this paper are (i) to explore the feasibility of FTA between India and Japan, (ii) to measure the impact of 'behind the border' constraints on bi-lateral trade between India and Japan, (iii) to simulate the gains due to various preferential trade agreements (PTAs), and FTA between these two countries, and finally, (iv) what policy conclusions can be drawn as inputs into the policymaking process of FTA between India and Japan.

The paper is arranged as follows: Section II examines the feasibility of FTA between India and Japan by measuring the trade intensity indices. In section III, theoretical framework, data, and methodology of measuring the trade impacts of PTAs and FTA between Japan and India are discussed. Section IV deals with the gravity modeling including the impact of 'behind the border' constraints on trade flows, and simulation procedures measuring the trade impacts of PTAs and FTA. Simulation results are analyzed in Section V. Section VI provides policy conclusions of this study.

\section{II: Feasibility of FTA between India and Japan: An Analysis of Trade Intensities}

FTAs between any two countries or regions would provide maximum gains from trade to countries involved, if countries/regions exhibit significant potential for trade with each other. Therefore, it is imperative to examine whether there is any potential for increasing the trade between India and Japan. Whether there is any trade potential between any two countries can primarily be examined by measuring the intensity of trade between them. ${ }^{2}$ If the intensity between two countries is low, it is obvious that two countries have much trade potential to reap between them. Bilateral trade relationships between India and Japan, which is described in terms of import and export intensity indices, helps to identify how intensively the countries are trading with each other. Trade intensity index is defined as a ratio of the share of one

\footnotetext{
${ }^{1}$ FTAs negotiated by Japan are called "Economic Partnership Agreements" (EPAs), as the government holds that the term "free trade agreement" doesn't capture the broader integration of economic and social policies that these treaties aim to achieve between the partner countries. However, these EPAs are similar in coverage to a typical FTA from the US, or the EU, if less ambitious on the content. ${ }^{2}$ Export performance of two countries can also be measured through revealed comparative advantage (RCA) index.
} 
country's trade with another country to the other country's share of world trade (Drysdale and Garnaut, 1982). When multiplied by 100, the value of index ranges from 0 to 100 . If the value is 0 , it implies no trade relationship between partner countries. On the other hand, if the value of import intensity index is more (or less) than 100 , it indicates that country $i$ is importing more (or less) from country $j$ than might be expected from that country's share in total world trade. In export too, if the value is 0 or nearer to 0 , it implies export link between these two countries is negligible and if the value is nearer to 100 that indicates that performance is significant and if it exceeds 100 it indicates that country $i$ is exporting more to country $\mathrm{j}$ than might be expected from that country's share in world trade.

The Import Intensity Index between Japan and India ( MII JIt $_{\text {}}$ ) is shown as follows:

$$
\mathrm{MI}_{\mathrm{JIt}}=\left[\mathrm{M}_{\mathrm{JI}} / \mathrm{M}_{\mathrm{J}}\right] /\left[\mathrm{X}_{\mathrm{I}} /\left(\mathrm{X}_{\mathrm{W}}-\mathrm{X}_{\mathrm{J}}\right)\right]
$$

Where:

$$
\begin{array}{ll}
M_{\mathrm{JI}} & =\text { Import intensity index of Japan with India } \\
\mathrm{M}_{\mathrm{JI}} & =\text { Import of Japan from India } \\
\mathrm{M}_{\mathrm{J}} & =\text { Total import of Japan } \\
\mathrm{X}_{\mathrm{I}} & =\text { Total export of India } \\
\mathrm{XW} & =\text { Total world export, } \\
\mathrm{X}_{\mathrm{J}} & =\text { Total export of Japan } \\
\mathrm{t} & =1995 \ldots \ldots 2005
\end{array}
$$

Export Intensity Index (XII) can also be measured in the similar way:

$$
\mathrm{XI}_{\mathrm{JI}}=\left[\mathrm{X}_{\mathrm{JI}} / \mathrm{X}_{\mathrm{J}}\right] /\left[\mathrm{M}_{\mathrm{I}} /\left(\mathrm{M}_{\mathrm{w}}-\mathrm{M}_{\mathrm{J}}\right)\right]
$$

Where:

$$
\begin{aligned}
& \mathrm{XI}_{\mathrm{J}}=\text { Export intensity index of Japan with India } \\
& \mathrm{X}_{\mathrm{JI}}=\text { Export of Japan to its trading partner India } \\
& \mathrm{X}_{\mathrm{J}} \quad=\text { Total export of Japan } \\
& \mathrm{M}_{\mathrm{I}}=\text { Total imports of India } \\
& \mathrm{Mw}=\text { Total world imports } \\
& \mathrm{M}_{\mathrm{J}}=\text { Total imports of Japan } \\
& \mathrm{t} \quad=1995 \ldots .2005
\end{aligned}
$$

Similarly, the export intensity index ( $\mathrm{XI}_{\mathrm{IJt}}$ ) and import intensity index ( $\mathrm{MI}_{\mathrm{IJt}}$ ) for India can be constructed. Export and import intensity indices of both Japan and India are calculated from 1995 to 2005. The trends of export intensities and import intensities of both Japan and India are shown in Table 1. Export and import intensities of both India and Japan have declined over the years. Japan's import intensity index was 121.13 during 1995, which drastically declined to 55.45 during 2005 . On the other hand, its export intensity index with respect to India was 72.10 during 1996 that too declined to 41.24 during 2005 . These figures clearly indicate that Japan's imports from India have declined much more than its exports to India. This may be due to the 
fact that Japan's import items from India are basically composed of primary and intermediary goods, whose demands are inelastic compared to its exports items to India. Japan's both import and export intensities are well bellow 100, which implies that it is trading much less with India than might be expected from Japan's share in world trade. This implies Japan has much potential to increase its trade with India.

India's export intensity with respect to Japan has declined substantially over the years too, which may seen from the fact that export index has declined from 101.1 during 1995 to 46.95 during 2005. One can conclude from such a declining trend that India has not diversified its export basket over the years to Japanese market, and it basically exported the same items, whose demands have been declining over the years. It shows its commodity concentration in exports is more than in its imports from Japan. In the import front also, trade intensity index has declined. During 1995, import intensity index was 73.74, which declined to 48.13 during 2005. However, this downturn is much less pronounced compared to the downslide in exports. Downward trend in imports may be attributed to the fact that India mainly imports machinery, transport equipments and capital goods from Japan. Since increasing number of Japanese companies are operating in India in these lines of production, its demand for imports has been less pronounced. The trends of both export and import intensity indices of India and Japan are shown in Fig. 1. The overall implication is that both India and Japan do have substantial potential to increase their trade between them. Next, it is important to identify how much tariffs and other non-tariff barriers constrain both India and Japan from realizing their trade potential with each other.

Table 1 : Import and Export Intensities of Japan and India, 1995-2005

\begin{tabular}{|c|c|c|c|c|}
\hline Year & $\mathrm{MI}_{J \mathrm{It}}$ & $X I_{J I t}$ & $\mathrm{Ml}_{\mathrm{IJt}}$ & $\mathbf{X I}_{\mathrm{IJt}}$ \\
\hline 1995 & 121.13 & 72.10 & 73.74 & 101.10 \\
\hline 1996 & 115.21 & 74.77 & 70.54 & 88.98 \\
\hline 1997 & 111.24 & 69.08 & 69.65 & 86.59 \\
\hline 1998 & 114.75 & 83.35 & 88.13 & 94.58 \\
\hline 1999 & 100.03 & 67.40 & 72.78 & 82.93 \\
\hline 2000 & 88.10 & 66.28 & 51.18 & 67.44 \\
\hline 2001 & 79.92 & 58.35 & 66.86 & 60.50 \\
\hline 2002 & 68.80 & 47.41 & 47.29 & 66.38 \\
\hline 2003 & 61.21 & 50.69 & 56.84 & 51.60 \\
\hline 2004 & 58.83 & 47.05 & 48.68 & 49.21 \\
\hline 2005 & 55.45 & 41.24 & 48.13 & 46.95 \\
\hline
\end{tabular}

\footnotetext{
$\mathrm{Ml}_{\mathrm{JIt}}=$ Japan's Import Intensity Index with respect to India.

$\mathrm{XI}_{\mathrm{Jt}}=$ Japan's Export Index with respect to India.

$M_{l J t}=$ India's Import Intensity Index with respect to Japan.

$\left.X\right|_{\mid J t}=$ India's Export Intensity Index with respect to Japan.

J= Japan; I=Japan; t= 1995.............2005.
} 


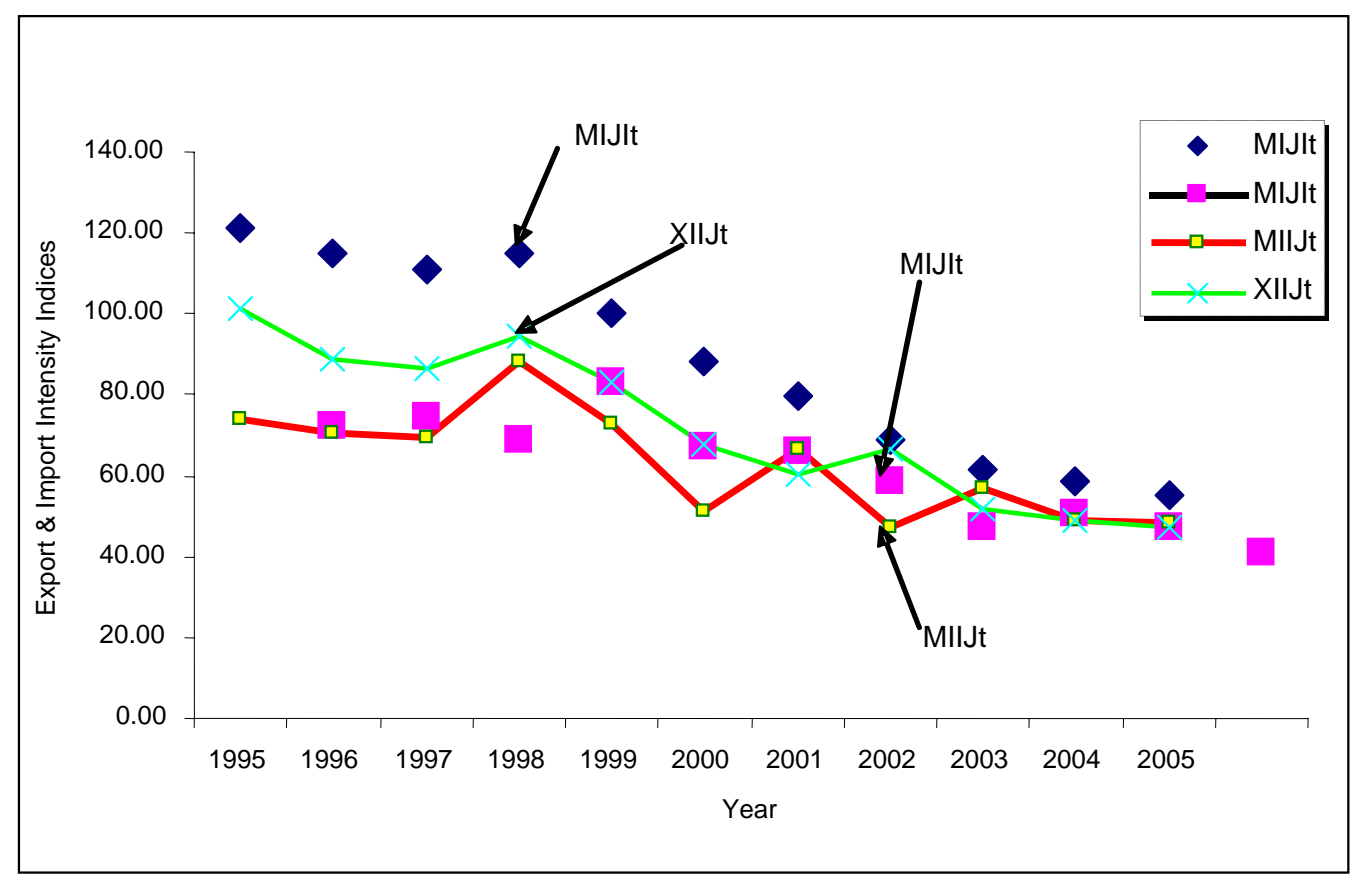

Figure 1: Import \& Export Intensities of India and Japan

\section{III: Theoretical Framework, Methodology, and Data}

\section{(a) Theoretical Framework}

Analytical tool for identifying the factors constraining trade flows and measuring the impact of preferential trading arrangements (PTAs) and free trade arrangement (FTA) on trade flows between countries is the well-known gravity model popularised by Tinbergen (1962), Anderson (1979), Bergestrand (1985), Frankel (1993), and Deardorff (1995) among others. Trade flows can be restricted by "natural barriers" (e.g. distance between countries) and restrictive policy oriented "artificial" barriers in the form of high tariff and non-tariff barriers. ${ }^{3}$ In order to overcome the "artificial" barriers, it is argued that countries are vying for regional and bilateral trading arrangements.

A number of different specifications of the Gravity Model has been used in the literature, depending mostly upon: (i) the objective of the study, and (ii) type of the sample data used. In most of the existing studies, the bilateral trade flows have been explained by variables like GNP (proxy for the size of countries), GNP per capita (proxy for the degree of development), trade restrictive variables like tariff and nontariff barriers, distance, adjacency, linguistic links, etc. Frankel's (1993) model was extensively used in the literature in the context of examining the impact of

\footnotetext{
3 Drysdale and Garnaut (1982) classified the resistances to trade as 'objective' and 'subjective' constraints, which respectively refer to 'natural' and 'artificial' barriers. Balwin and Taglioni (2006) grouped the resistances to trade into 'natural' and 'manmade' barriers referring to 'natural' and 'ariticial' constraints respectively. Kalirajan (2007) distinguished the constraints to trade flows by classifying them into 'natural', 'behind the border', and 'explicit beyond the border', and 'implicit beyond the border' constraints.
} 
regionalism on trade flows between countries. For example, Safadi and Yeats (1993) have estimated the increase in intraregional trade of NAFTA due to PTAs and FTA using Frankel's model. Srinivasan and Canonero (1993, 1994, and 1995), drawing on Frankel, estimated the tariff elasticities to show the impact of preferential trade arrangements on the trade flow of SAARC countries.

There are two particular limitations concerning Frankel's (1993) modeling and estimation. First, he uses a pooled cross-country gravity equation using data from more than sixty countries to determine the existence of intraregional bias in trade and found evidence against openness not only in North American and European trade, but also in East Asian trade. In contrast to similar studies, Dhar and Panagarya (1996) estimated both country specific and pooled cross-country gravity equations to examine the question of openness in North America, Europe and East Asia. An important finding of their study is that a country-specific gravity equation can explain trade flows between countries better than a cross country gravity equation because the latter makes large difference across countries. Secondly, while these conventional gravity model studies admit the importance of restrictive 'policy induced' constraints, which are otherwise called 'behind the border' constraints, on home country's exports, usually, these factors are merged with the 'statistical random error term' with 'normal properties' by implying that they are randomly distributed across observations. However, such a modeling in empirical work does lead to incorrect estimates of potential trade and does not also reflect the reality. Therefore, the lack of any appropriate measures to account for this problem in empirical studies of international trade could be insightful. Recently, Anderson and van Wincoop (2003) as a way of tackling this problem suggested an approach to modify the conventional gravity model specification by including a multilateral resistance term to obtain more correct estimates. However, their modeling of the multilateral resistance term as a function of distance and tariffs only, ignores the presence and impact of variations in 'behind the border' constraints on home country's exports. Further, in the presence of heteroscedasticity, the OLS estimation of their log-linearized gravity model would lead to biased estimates.

Kalirajan (2007) suggested an alternative method without imposing heavy data requirements on researchers, which can be used in situations when researchers do not have full information on all restrictive 'policy induced' constraints in home country and in partner countries. The method involves measuring the combined effects of 'behind the border' constraints for a given level of 'beyond the border' constraints that exist in partner countries. The theoretical model followed in this paper is as follows:

Following Drysdale and Garnaut (1982), and Baldwin and Taglioni (2006), and drawing on Kalirajan (2007), it is argued that trade flows between countries are negatively influenced by the following four factors: (a) geographical distance; (b) 'behind the border' constraints that emanate from the existing infrastructural and institutional inefficiencies and rigidities in home country; (c)'explicit beyond the border' constraints that emanate from tariffs and exchange rate on which home country does not have any control; and (d) 'implicit beyond the border' constraints that emanate from the existing infrastructural and institutional inefficiencies and rigidities in partner country on which home country does not have any control. Bilateral, regional, and multilateral trade agreements do aim at eliminating both 'behind' 
and 'beyond' the border constraints. Though geographical distance and 'explicit beyond the border' constraints are measurable, researchers may not have full information on 'behind the border' and 'implicit beyond the border' constraints. Then, the imprecision of excluding these factors in modeling gravity equations leads to heteroskedastic error terms and the log-linearization of the empirical model in the presence of heteroskedasticity leads to inconsistent estimates because the expected value of the logarithm of a random variable depends on higher-order moments of its distribution (Silva and Tenreyro, 2003). Also, this imprecise specification affects the normality assumption of the error term. Fixed effects models proposed to tackle the issue of heterogeneity problem by Matyas (1997) are not formulated based on any theoretical ground.

In a sense, heteroscedasticity and non-normality are interrelated. Heteroscedasticity is a property of the conditional distribution of the dependent variable in a regression model, and the effect of heteroscedasticity with respect to the variables that move variances around is generally non-normality. This kind of situation, where the structure of heteroscedasticity is unknown, is quite common in many empirical analyses in economics. This type of deviation from homoscedastic residuals appears to be mainly due to characteristics specific to observations that are not easily quantifiable. In the case of the standard gravity equation, the 'behind the border' and 'implicit beyond the border' constraints variables are not easily quantifiable as discussed by Roemer (1977: 318). In this situation, OLS estimation leads to biased results and the procedures developed for estimating stochastic frontier production functions (Aigner, Lovell, and Schmidt, 1977; and Meeusen and van den Broeck, 1977), can be used to estimate the gravity equation incorporating 'behind the border' and 'beyond the border' constraints along with geographical distance constraint factor and other factors influencing trade flows.

\section{(b) Methodology}

Unlike Frankel's and similar models, drawing on Dhar and Panagariya (1996), this paper uses country-specific trade data for India and Japan. The selected sample sizes of the partner countries, which are fixed at 50 for both India and Japan, represent about 80 percent of exports and therefore, the estimated models can be considered to be representative models for these economies in a general equilibrium framework. The analysis would measure the impact of PTAs only by the proportionate change in exports of Japan to India and vice versa in dollars. The higher the initial tariff level on trade between partners, the greater the final effect of reduction and elimination of tariffs. However, tariff is only one of several factors that determine the impact of PTA on trade. In assessing the impact, the following factors should be noted. First, as can be seen from the tariff data, the initial tariff levels of India are quite high compared to that of Japan. Therefore, intuitively, Japan's increase in exports to India will be much higher compared to the latter's exports to the former because of its lower average tariffs. In the short run, Japan will be the beneficiary to trade with India because of asymmetry in tariff structures in both the countries. Secondly, elasticities indicating the proportionate response of bilateral trade to changes in tariffs, the initial tariff levels as well as initial level of exports are relevant for determining the absolute changes in exports in both India and Japan following the PTAs and FTA. 
A comparative static analysis of tariff reductions under different scenarios and its effects on increase in exports of both Japan and India has been undertaken. The objective of this analysis is to estimate the trade potentials between Japan and India, and to examine the costs and benefits of different PTAs and FTA to both countries. Four hypothetical scenarios in this study are as follows:

(i) $25 \%$ across the board tariff cuts by both countries;

(ii) $50 \%$ across the board tariff cuts by both countries;

(iii) $75 \%$ across the board tariff cuts by both countries; and

(iv) $100 \%$ tariff cuts i.e. free trade between India and Japan.

\section{(c) Data}

Data on exports of both Japan and India with their 50 top trading partners in terms of rankings of total volume of exports are taken from the UN COMTRADE database provided through the online WITS software developed by the World Bank and UNCTAD. There are gaps in the COMTRADE database for some countries. In such cases, exports data were taken from IMF's Direction of Trade Statistics. Both GDP and population data of the respective countries are taken from the online data provided by the UN Statistical Division, UN and the World Development Indicators 2006. Tariff data for the analysis are taken from TRAINS CD-ROM compiled by UNCTAD provided in the WITS software. The variable REXR aims to account for significant changes in real exchange rate in Japan, India and its 50 top trading partners. REXR is an index with base $2000=100$ for the real exchange rate of the domestic currencies of Japan, India and its 50 trading partners. REXR is calculated using the nominal exchange rate and GDP deflator from IMF's International Financial Statistics (exchange rate is market value and average for the period). Data on distance are calculated from the methodology, which is discussed in the next section. The period of analysis is 2005. The computer software Frontier 4.1 is used to estimate stochastic frontier gravity model, which is explained in details in Coelli (1996).

\section{IV: Analysis of Empirical Results: Impact of Constraints on Trade Flows}

\section{(a) Empirical Model}

Deviating from the conventional gravity model and drawing heavily on Kalirajan (2007), this study has used the stochastic frontier gravity model, which facilitates incorporating the 'behind the border' and 'beyond the border' factors affecting free flow of trade into the empirical model. As discussed earlier, the impact of the 'beyond the border' constraints can be divided into two groups, viz. 'explicit beyond the border constraints' and 'implicit beyond the border constraints'. Of these, the impact of 'explicit beyond the border constraints' on home country's exports may be measured from the coefficients of variables such as average tariffs and real exchange rate. These two variables are included in the gravity model for both India and Japan as follows:

$$
\begin{aligned}
& \ln \mathrm{Xij}=\alpha_{0}+\beta_{1} \ln (\mathrm{GDPj})+\beta_{2} \ln \left(\mathrm{Popn}_{\mathrm{j}}\right)+\beta_{3} \ln \left(\mathrm{Dist}_{\mathrm{ij}}\right)+\beta_{4} \ln \left(\text { Tariff }_{\mathrm{j}}\right)+\beta_{5} \ln \\
& \left(\operatorname{REXR}_{\mathrm{j}}\right)-\mathrm{u}_{\mathrm{i}}+\mathrm{v}_{\mathrm{ij}}
\end{aligned}
$$




\begin{abstract}
Where
Xij $=$ Exports of country ' $i$ ' to country ' $\mathrm{j}$ '

GDPj = Gross Domestic Product of country j (i.e. importing country)

Popj = Population of country 'j' (i.n. population of importing country)

Dstij = Distance between country ' $\mathrm{i}$ ' and ' $\mathrm{j}$ '

Tariffj = Average weighted tariffs of the importing country

REXRj $=$ Real exchange rate of the currencies of importing countries

$\mathrm{u}_{\mathrm{i}} \quad=$ Combined effects of "behind the border" constraints that prevent concerned country (India/Japan)from reaching its potential with its partner country. In other worlds, $\exp (\mathrm{u})$, which is the ratio of actual to estimated exports, can be called as export efficiency of India/Japan.

$\mathrm{v}_{\mathrm{i}} \quad=$ Combined effects of "beyond the border" constraints and 'usual statistical' errors.

$\mathrm{i}$, and $\mathrm{j} \quad=$ India and Japan respectively.

$\mathrm{u}$ takes values either 0 or greater than 0 and it is usually assumed to follow a truncated (at 0 ) normal distribution, $\mathrm{N}\left(\mu, \sigma_{\mathrm{u}}^{2}\right)$. When $\mathrm{u}$ takes the value 0 , this means that the influence of 'behind the border' constraints is not an important barrier to exports. When $\mathrm{u}$ takes the value greater than 0 , this means that the influence of 'behind the border' constraints is an important barrier to export flows. The double-sided error term $\mathrm{v}_{\mathrm{ij}}$, which is usually assumed to be $\mathrm{N}\left(0, \sigma_{\mathrm{v}}^{2}\right)$, captures the influence on export flows of 'beyond the border' constraints existing in partner countries, which are not under the control of the exporting country, and other left out variables, including measurement errors that are randomly distributed across observations in the sample. The period of analysis is 2005 . Further, all the above data except relative distance, vi and ui are in yearly aggregates.
\end{abstract}

The analysis is done using total aggregated exports data and also using major commodity-specific data for both India and Japan. We have taken 10 major commodities at the 2-digit HS categories for both the countries. These commodities/commodity groups are selected on the basis of their importance in total exports to each other. These commodities are ranked from 1 to 10 for both India and Japan, the total of which cover more than 80 per cent of total exports to its trading partner (i.e. India and Japan). In the case of Japan, 10 highest ranking commodities exported to India at the 2-digit level are: boilers, machinery and machine parts (HS 84), electrical machinery equipments and parts (HS 85), motor vehicles (railway/tramway) rolling stock (HS 87), iron \& steel (HS 72), optical photo, cinematic and measurement tools (HS 90), organic chemicals (HS 29), plastic and articles of plastic (HS 39), articles of iron and steel (HS 73), photographic and cinematic goods(HS 37) and rubber and articles of rubber (HS 40). India's top 10 commodities/commodity groups to its total exports to Japan during 2005 are: natural/cultured pearls, precious stones (HS 71), ores, slag and ash ( HS 26), mineral fuels, oils and products of these items (HS 27), fish and fish proucts (HS 03), residues and waste from the food industry (HS 23), organic chemicals(HS 29), clothing and clothing accessories (HS 62), boilers, machinery and machine parts (HS 84), cotton (HS 52) and iron and steel (HS 72). 
One of the most important components of the gravity model is the distance variable, which is measured in miles between capitals of the respective countries and is computed in the following way ( Egger 2002):

$D_{\mathrm{JB}}=\mathrm{r} \cdot \operatorname{arcos}\left[\sin \left(\varphi_{\mathrm{J}}\right) \cdot \sin \left(\varphi_{\mathrm{B}}\right)+\cos \left(\varphi_{\mathrm{J}}\right) \cdot \cos \left(\lambda_{\mathrm{B}}-\lambda_{\mathrm{J}}\right)\right.$

Where $D_{J B}$ is the distance between Japan/India and its trading partner i.e distance between their capitals in miles $/ \mathrm{kms}, \mathrm{r}$ is the earth radius in miles, $\varphi_{\mathrm{J}}$ and $\varphi_{\mathrm{B}}$ are radian measures of the parallel of latitude of the two countries' capitals, and $\left(\lambda_{B}-\lambda_{J}\right.$ ) is the radian measure of the difference in meridians of the two countries' capitals. Distance basically measures transport cost, which is, in other words, represents trade costs. Assuming that all countries are of a circular area, one can compute the radius ( $r$ ) for all countries based on data provided in the world atlas. When production is concentrated in the centre of the circle (the country's capital or economic area) the average distance $(m)$ between the centre and the other points on the circular area is derived from the following condition:

$m^{2} \pi=r^{2} \pi-m^{2} \pi$

Thus the circular area is splitted in an outer concentric circular area of the same size. Solving for $m$ yields,

$m=\sqrt{-} \mathrm{r}^{2} / 2$.

Tariff is another variable of interest in this analysis. Entire exercise rests on the reductions in tariffs under different scenarios including the free trade option. Weighted average tariffs of all commodities (i.e., 10) at the 2-digit level and weighted average tariffs of total imports for India and Japan and its 50 top ranking trading partners for the year 2005 were considered for this study. Tariffs are MFN tariffs rather than ad valorem duties.

\section{(b) Analysis of Results}

Based on equation (1), the parameters of the gravity models both for India and Japan were estimated, which are shown in Table $2 \& 3$. Mean efficiencies of exports of Japan and India, which indicate how effective are the negative influences of 'behind the border' constraints for the existing levels of 'implicit beyond the border' constraints on export flows between India and Japan, are shown in Table 4.

Table 2 shows the MLE estimations of India's exports to Japan and Table 3 shows the MLE estimations of Japan's exports to India. The coefficients of these equations do confirm the theoretical predictions in terms of signs. The coefficients of all variables are significant at least at the 10 percent levels in both cases. The bigger is the trading partner, the more significant is the bilateral trade due to higher GDP and thus due to the surging domestic demand of the importing country. The more is the distance between two trading partners, higher is the transaction cost that adds to the total cost, therefore, less is traded between the countries. Higher the population of the importing country, higher will be the trade between two countries because of higher domestic demand of the importing country. Higher is the tariffs in the importing country, less is the trade due to trade costs. Finally, higher real exchange rate means export earnings are more, therefore, more will be the exports i.e. relationship between real exchange rate and exports is positive and it is negative on imports. 
Table 2: Maximum Likelihood Estimates of the Stochastic Frontier Gravity Equation for India's Exports to partner countries including Japan

\begin{tabular}{|c|c|c|c|c|c|c|c|c|c|c|c|}
\hline Variables & Total Exports & HS 3 & HS 23 & HS 26 & HS 27 & HS 29 & HS 52 & HS 62 & HS 71 & Hs 72 & HS 84 \\
\hline \multirow[t]{2}{*}{ Constants } & 14.04 & 10.04 & 18.57 & 6.36 & 11.48 & 9.14 & 12.41 & 7.86 & 6.16 & 11.33 & 10.12 \\
\hline & (7.57) & $(2.77)$ & (3.73) & (2.11) & $(4.04)$ & (10.02) & (5.96) & (3.73) & $(1.94)$ & $(5.33)$ & (4.26) \\
\hline \multirow[t]{2}{*}{ GDP } & 0.31 & 0.68 & 0.72 & 0.65 & 0.29 & 0.55 & 0.17 & 0.42 & 0.68 & 0.2 & 0.31 \\
\hline & $(4.78)$ & $(4.79)$ & (3.64) & (3.16) & $(1.90)$ & $(11.76)$ & (1.89) & (3.51) & $(3.64)$ & $(1.83)$ & (3.01) \\
\hline \multirow[t]{2}{*}{ Population } & 0.15 & 0.06 & -0.211 & 0.089 & -0.11 & 0.059 & 0.15 & -0.3 & -0.18 & 0.073 & 0.05 \\
\hline & $(1.97)$ & (2.33) & $(-1.97)$ & $(2.34)$ & $(-2.59)$ & (1.96) & (1.24) & $(-1.9)$ & $(-1.79)$ & $(1.84)$ & (1.87) \\
\hline \multirow[t]{2}{*}{ Distance } & -0.7 & -0.9 & -2.32 & -0.68 & -0.36 & -0.51 & -0.52 & -0.14 & -0.45 & -0.4 & -0.38 \\
\hline & $(4.15)$ & $(2.20)$ & $(-5.61)$ & $(-1.93)$ & $(-4.71)$ & $(-5.03)$ & $(-3.6)$ & $(-2.9)$ & $(-2.2)$ & $(-2.1)$ & $(-1.81)$ \\
\hline \multirow[t]{2}{*}{ Tariff } & -0.14 & -0.07 & -0.3 & -0.053 & -0.035 & -0.17 & -0.11 & -0.08 & -0.28 & -0.12 & -0.062 \\
\hline & $(-2.14)$ & $(-1.88)$ & $(-3.12)$ & $(2.49)$ & $(2.36)$ & $(-6.65)$ & $(-1.8)$ & $(-1.9)$ & $(-2.02)$ & $(-1.86)$ & (1.96) \\
\hline \multirow[t]{2}{*}{ REXR } & 0.03 & 0.01 & 0.35 & 0.19 & 0.026 & 0.08 & 0.033 & 0.19 & 0.026 & 0.083 & 0.035 \\
\hline & $(-.54)$ & $(-.71)$ & $(3.36)$ & $(-2.43)$ & $(-2.33)$ & $(2.30)$ & (2.61) & $(-2.63)$ & $(-2.0)$ & $(1.93)$ & $(-1.88)$ \\
\hline \multirow[t]{2}{*}{$\sigma^{2}$} & 0.47 & 4.59 & 2.4 & 3.62 & 1.66 & 1.13 & 0.56 & 0.98 & 3.5 & 0.76 & 0.52 \\
\hline & (3.21) & $(2.54)$ & $(2.50)$ & (3.91) & $(2.14)$ & $(2.70)$ & (2.83) & $(2.84)$ & $(5.43)$ & $(3.60)$ & (3.07) \\
\hline \multirow[t]{2}{*}{$\Gamma$} & 0.64 & 0.96 & 0.65 & 0.67 & 0.51 & 0.91 & 0.74 & 0.65 & 0.72 & 0.59 & 0.64 \\
\hline & $(4.01)$ & $(22.93)$ & $(6.00)$ & $(5.05)$ & $(4.30)$ & $(13.00)$ & $(6.01)$ & $(5.22)$ & $(5.34)$ & $(3.07)$ & (7.84) \\
\hline M & -0.09 & 0.43 & -0.12 & -0.1 & -0.059 & 0.36 & -0.09 & 0.089 & -0.0097 & -0.094 & -0.092 \\
\hline \multirow[b]{2}{*}{$\begin{array}{l}\text { Log Likelihood } \\
\text { Function }\end{array}$} & $(-2.05)$ & (2.23) & $(-1.88)$ & $(-1.91)$ & $(-2.04)$ & $(2.77)$ & $(-2.0)$ & $(1.93)$ & $(-1.87)$ & $(-2.04)$ & $(-2.09)$ \\
\hline & -52.08 & -84.15 & -92.8 & -103.11 & -83.69 & -47.46 & -56.13 & -70.38 & -102.28 & -63.91 & -54.42 \\
\hline
\end{tabular}

*Values in the brackets are t-ratios. 
Table 3: Maximum Likelihood Estimates of the Stochastic Frontier Gravity Equation for Japan's Exports to partner countries including India

\begin{tabular}{|c|c|c|c|c|c|c|c|c|c|c|}
\hline Total Exports & HS 29 & HS 37 & HS 39 & HS 40 & HS 72 & HS 73 & HS 84 & HS 85 & HS 87 & Hs 90 \\
\hline 23.75 & 13.83 & 13.96 & 17.76 & 12.56 & 26.71 & 19.21 & 20.59 & 17.09 & 8.25 & 18.31 \\
\hline 0.14 & 0.97 & 0.96 & 0.63 & 0.46 & 0.31 & 0.36 & 0.52 & 0.78 & 0.51 & 0.6 \\
\hline (2.05) & (5.71) & (19.73) & $(4.46)$ & $(4.48)$ & $(2.37)$ & (3.17) & $(4.57)$ & $(5.41)$ & $(5.17)$ & $(4.90)$ \\
\hline 0.31 & -0.011 & -0.28 & 0.19 & -0.0071 & 0.19 & 0.0029 & 0.19 & -0.079 & -0.035 & 0.16 \\
\hline (2.39) & $(-2.07)$ & $(-6.97)$ & $(1.97)$ & $(-1.86)$ & (2.28) & $(-1.93)$ & $(1.97)$ & $(-1.9)$ & $(-2.37)$ & (2.30) \\
\hline-1.2 & -1.67 & -1.52 & -1.66 & -0.78 & -2.23 & -1.38 & -1.39 & -1.45 & -0.064 & -1.58 \\
\hline$(-4.17)$ & $(-6.15)$ & $(-19.24)$ & $(-8.4)$ & $(-3.64)$ & $(-12.97)$ & $(-7.86)$ & $(-5.3)$ & $(-5.4)$ & $(-2.49)$ & $(-8.04)$ \\
\hline-0.16 & -0.19 & -0.07 & -0.2 & -0.002 & -0.1 & -0.065 & -0.096 & -0.22 & -0.095 & -0.24 \\
\hline$(-1.98)$ & $(-1.86)$ & $(-1.89)$ & $(-2.3)$ & $(-1.94)$ & (2.61) & (1.83) & $(-2.4)$ & $(-2.8)$ & $(-2.15)$ & $(-3.07)$ \\
\hline 0.13 & -0.0006 & 0.012 & 0.03 & 0.03 & 0.055 & 0.056 & 0.06 & 0.07 & 0.036 & 0.044 \\
\hline 0.71 & 1.4 & 2.67 & 1.03 & 0.58 & 1.02 & 0.75 & 0.75 & 0.85 & 0.51 & 0.67 \\
\hline (3.55) & (3.40) & $(9.50)$ & $(2.73)$ & (5.25) & (4.93) & (3.45) & $(2.91)$ & $(1.85)$ & $(2.91)$ & $(4.52)$ \\
\hline 0.66 & 0.56 & 0.89 & 0.62 & 0.58 & 0.61 & 0.68 & 0.72 & 0.37 & 0.72 & 0.68 \\
\hline (6.01) & $(4.86)$ & $(21.35)$ & $(7.05)$ & (6.42) & (6.77) & $(5.32)$ & $(7.09)$ & $(3.02)$ & $(9.05)$ & (8.44) \\
\hline-0.086 & -0.096 & -0.54 & -0.094 & 0.08 & -0.02 & -0.09 & 1.47 & 0.29 & -0.088 & -0.079 \\
\hline$(-2.05)$ & $(-2.03)$ & $(-1.96)$ & $(-2.2)$ & (2.31) & $(-1.92)$ & $(-1.82)$ & $(2.98)$ & (1.88) & $(-1.96)$ & $(-2.06)$ \\
\hline-62.24 & -79.33 & -54.61 & -71.74 & -57.3 & -71.53 & -63.62 & -61.55 & -66.63 & -54.19 & -60.74 \\
\hline
\end{tabular}

${ }^{\star}$ Values in the brackets are t-ratios. 
Table 4: Mean Efficiency* of Exports of India and Japan (Sectorwise), 2005

\begin{tabular}{clllll}
\hline & & & & & \\
\hline HS Cat & Commodity Groups (India) & Mean Efficiency & HS Cat. & Commodity Groups (Japan) & Mean Efficiency \\
\hline & & & & & \\
& & & & & \\
71 & Natural/cultured pearls, prec stone & 0.62 & 84 & Nuclear reactors, boilers, \& machy. & 0.47 \\
26 & Ores, slag and ash. & 0.70 & 85 & Electrical mchy equip parts thereof & 0.74 \\
27 & Mineral fuels, oils \& product of th & 0.62 & 87 & Vehicles o/t railway/tramway roll-stock & 0.69 \\
03 & Fish \& crustacean, mollusk \& other & 0.36 & 72 & Iron and steel. & 0.62 \\
23 & Residues \& waste from the food industry & 0.62 & 90 & Optical, photo, cine, meas, checkin & 0.70 \\
29 & Organic chemicals. & 0.46 & 29 & Organic chemicals. & 0.61 \\
62 & Art of apparel \& clothing access, $n$ & 39 & Plastics and articles thereof. & 0.68 \\
84 & Nuclear reactors, boilers, \& machy & 0.61 & 68 & Articles of iron or steel. & 0.60 \\
52 & Cotton. & 0.60 & 37 & Photographic or cinemographic goods. & 0.43 \\
72 & Iron and steel. & 0.69 & 40 & Rubber and articles thereof. & 0.62 \\
Total & All Commodities & 0.61 & Total & All Commodities & 0.64 \\
& & 0.60 & & & \\
\hline
\end{tabular}

* Mean efficiencies are based on 50-country average 
Table 5 : Tariff Elasticities of India and Japan (Sectorwise)

\begin{tabular}{|c|c|c|c|c|c|c|c|}
\hline HS Cat & Commodity Groups (India) & $\begin{array}{c}\text { India's Exports to } \\
\text { Japan } \\
(' 000 \$), 2005\end{array}$ & Tariff Elast. & HS Cat & t. Commodity Groups (Japan) & $\begin{array}{c}\text { Japan's Exports } \\
\text { to India } \\
\text { ('000 \$), } 2005\end{array}$ & Tariff Elast. \\
\hline 71 & Natural/cultured pearls, prec stone & $488,605.659$ & -0.28 & 84 & Nuclear reactors, boilers, \& mchy & $1,099,474.437$ & -0.1 \\
\hline 26 & Ores, slag and ash. & $411,368.044$ & -0.05 & 85 & Electrical mchy equip parts thereof & $410,811.980$ & -0.22 \\
\hline 27 & Mineral fuels, oils \& product of th & $225,733.470$ & -0.035 & 87 & Vehicles o/t railw/tramw roll-stock & $405,091.575$ & -0.01 \\
\hline 03 & Fish \& crustacean, mollusc \& other & $224,521.846$ & -0.07 & 72 & Iron and steel. & $247,401.974$ & -0.1 \\
\hline 23 & Residues \& waste from the food indu & $133,528.577$ & -0.3 & 90 & Optical, photo, cine, meas, checkin & $217,915.158$ & -0.25 \\
\hline 29 & Organic chemicals. & $108,707.014$ & -0.17 & 29 & Organic chemicals. & $217,204.571$ & -0.19 \\
\hline 62 & Art of apparel \& clothing access, $n$ & $104,612.614$ & -0.08 & 39 & Plastics and articles thereof. & $125,251.240$ & -0.2 \\
\hline 84 & Nuclear reactors, boilers, \& mchy & $72,068.754$ & -0.06 & 73 & Articles of iron or steel. & $115,313.592$ & -0.07 \\
\hline 52 & Cotton. & $67,440.708$ & -0.11 & 37 & Photographic or cinematographic goo & $75,071.353$ & -0.1 \\
\hline 72 & Iron and steel. & $37,321.414$ & -0.12 & 40 & Rubber and articles thereof. & $67,575.039$ & -0.02 \\
\hline Total & All Commodities & $2,481,606.235$ & -0.14 & Total & All Commodities & $3,439,909.518$ & -0.16 \\
\hline
\end{tabular}


The important results of Tables 2 and 3 are the significance and magnitude of the estimate of 'gamma', which is a ratio of the variance of $u$ showing the combined effects of 'behind the border' constraints to total variance of exports of home country. These results indicate that a very highly significant amount of variation in exports between India and its partner countries including Japan is due to its 'behind the border' constraints involving infrastructural and institutional inefficiencies and rigidities. Similar is the case with Japan's exports to its partner countries including India.

In terms of export efficiency, which is shown in Table 4, mean efficiencies for Japan are much low in photographic and cinematic goods (HS 37) and machinery and machine parts (HS 84) and mean efficiency is less than average in products groups belonging to iron and steel. In other categories mean efficiency is reasonable. As only cross section data of the countries are used in this paper, which ignores the dynamic effects, the results need to be interpreted with due care. In the case of exports of India to its trading partners including Japan, mean efficiency of all products/product categories are reasonable, barring HS 29, HS 52, HS 62, and HS 72. Thus, India appears to be less efficient in exporting particularly fish and fish products (i.e. purely primary goods). In exporting organic chemicals, India's efficiency is lower than that of Japan. Overall, India and Japan could increase their exports to their partner countries by about 40 percent and 36 percent respectively by eliminating the existing 'behind the border constraints' in India and Japan.

\section{V: Simulation Results}

Next, the analysis concerns working out the impact of PTAs and FTA on exports of both India and Japan to each other only. This exercise is a hypothetical scenario in which two countries start with a tariff reduction of 25 per cent at the initial stage and gradually reduce to 50 per cent in the second phase, 75 per cent in the third phase and complete elimination of tariffs in the final phase. All free trade arrangements start with preferential tariff arrangements (PTAs) with the negative lists of all trading partners. Invariably smaller countries start with a bigger negative list with longer transition periods. On the other hand, bigger countries start with a smaller negative list with shorter transition periods. Though Japan will start with a smaller negative list with a lower transition period, it will be the gainer in the short-run because of the existing high tariff regime in India. On the other hand, though India will start with a bigger negative list with a longer transition period, it will be the loser in the short run because of the existing smaller size of tariffs in Japan. In 2005, Japanese average (weighted) tariffs imposed on its imports from India was only 2.12 per cent, whereas India's average (weighted) tariffs imposed on its imports from Japan was as high as 15.36 per cent. This is a matter of high concern for India.

Given the estimated parametric values of $\beta_{4}$ from the fitted regression equation (1) for 10 commodity groups at 2-digit HS categories and total exports, which are given separately in Table 4 for convenience, the percentage increase in exports of Japan to India and vice versa due to changes in tariff rates at different scenarios as mentioned earlier in the methodology are worked out. The methodology for calculation of the increase in exports of one country due to PTAs and FTA to the markets of other countries is as follows: 
$\left[\exp \left\{\beta_{4} \log ((\mathrm{TRI}, \mathrm{J}) 1 /(\mathrm{TRI}, \mathrm{J}) 0)+1 / 2 \sigma^{2}\right\}-1\right] * 100$

An increase in exports of Japan to India due to change in tariffs of the latter country.

$\left.\left[\exp \left\{\begin{array}{lll}\beta_{4} \log ((\mathrm{TRJ}, \mathrm{I}) 1 /(\mathrm{TRJ}, \mathrm{I}) & 0\end{array}\right)+1 / 2 \sigma^{2}\right\}-1\right] * 100$

An increase in exports of India to Japan due to a change in tariffs of the latter country.

Where,

$\sigma^{2}=\sigma^{2} \beta_{4} \log (\mathrm{TR} I, \mathrm{~J})+\beta_{4} \log (\mathrm{TR} \mathrm{J}, \mathrm{I})$

Impact of different levels of tariff cuts through PTAs and FTA on India's exports to Japan is shown in Table 6. In the hypothetical comparative-static analysis, it is shown that if Japan completely eliminates tariffs on its imports from India, total exports of the latter to the former will increase by 0.3 per cent (i.e., even less than 1 per cent). Most significant increase in exports will be in HS 62 i.e., apparel and clothing, whose exports to the Japanese market will increase by 0.73 per cent i.e., the highest of all 10 major commodity groups at the 2-digit level groups. Next important item, which shows a higher growth is iron and steel and articles made of iron and steel (HS 72). Due to FTA, India's exports of this item to Japanese market will increase by 0.58 per cent, followed by cotton ( 0.52 per cent) in HS 52 and organic chemicals (i.e., 0.47 per cent) in HS category 29. These results show that simple tariff-based FTA won't make any significant impact on India's exports to Japan, since tariffs imposed by Japan on imports of most of these items are very insignificant, and in host of items even at the 2 digit level, there is no tariff in Japan. Tariff is only very high in apparel and clothing accessories and textiles and cotton. But even in the case of textiles and clothing, India is unlikely to withstand strong competition from China, which has already captured substantial share of the Japanese market. Secondly, Japan's imports of clothing basically consists of high value added items, whereas India exports mostly lower value clothing. Therefore, it is unlikely that India will get a better foothold in Japanese market, if two countries go ahead with the FTA. However, there is a caveat. This analysis has not considered the impact of non-tariff barriers on trade, which is phenomenally high in Japan than in India. Japan's agricultural market is highly protected in the form of tariff rate quota (TRQ) first, and then by exorbitant higher standards in the form of SPS (sanitary and phytosanitary standards) and TBT (technical barriers to trade). Unless Japan relaxes its SPS and TBT standards and liberalizes its agricultural market, India is unlikely to make any substantial gain from FTA. FTA should include liberalization of NTBs along with PTAs and FTA.

Table 7 shows the likely increase in Japan's exports to India due to different PTAs and FTA at aggregated and disaggregated level. The simulation results show that gains from India-Japan FTA is substantially high in the case of Japan's exports to India. This is simply because of the fact that Indian market is protected by much higher tariffs, probably India's average rate of tariffs is amongst the highest in the world at present. Though peak tariff has been reduced to 10 per cent in the recent budget, its collection rate is still hovering around 17 per cent, which is significantly high measured in any standards. This analysis is based on 2005 data, when India's average (wtd) tariffs on its imports from Japan was 15.36 percent compared to Japan's 2.12 percent for its imports from India. 
Table 6: Likely increase in India's exports to Japan under different PTAs and FTA, 2005

(Value in US '000 \$)

\begin{tabular}{|c|c|c|c|c|c|c|c|c|c|c|c|}
\hline \multirow[b]{2}{*}{$\begin{array}{l}\text { HS } \\
\text { Code }\end{array}$} & \multirow[b]{2}{*}{ Name of the Commodities } & \multirow{2}{*}{$\begin{array}{c}\text { India's exports to } \\
\text { Japan (2005) } \\
\text { '000 \$ }\end{array}$} & \multirow{2}{*}{$\begin{array}{c}\text { MFN Tariffs } \\
\text { (Wtd Avg) } \\
\text { of Japan (2005) }\end{array}$} & \multicolumn{4}{|c|}{ Increase in Exports (Value in '000 US \$) } & \multicolumn{4}{|c|}{ Percentage Increase } \\
\hline & & & & Scen.I & Scen.II & Scen.III & Scen.IV & Scen.I & Scen.ll & Scen.III & Scen.IV \\
\hline 71 & Natural/cultured pearls, prec stone & $488,605.659$ & 0.37 & 126.55 & 253.10 & 379.65 & 506.20 & 0.03 & 0.05 & 0.08 & 0.10 \\
\hline 26 & Ores, slag and ash. & $411,368.044$ & 0.01 & 0.51 & 1.03 & 1.54 & 2.06 & 0.00 & 0.00 & 0.00 & 0.00 \\
\hline 27 & Mineral fuels, oils \& product of th & $225,733.470$ & 2.31 & 45.63 & 91.25 & 136.88 & 182.51 & 0.02 & 0.04 & 0.06 & 0.08 \\
\hline 03 & Fish \& crustacean, mollusc etc & $224,521.846$ & 1.98 & 77.80 & 155.59 & 233.39 & 311.19 & 0.03 & 0.07 & 0.10 & 0.14 \\
\hline 23 & Residues \& waste from the food industry & $133,528.577$ & 0.23 & 23.03 & 46.07 & 69.10 & 92.13 & 0.02 & 0.03 & 0.05 & 0.07 \\
\hline 29 & Organic chemicals. & $108,707.014$ & 2.74 & 126.59 & 253.18 & 379.77 & 506.36 & 0.12 & 0.23 & 0.35 & 0.47 \\
\hline 62 & Art of apparel \& clothing access, $n$ & $104,612.614$ & 9.08 & 189.98 & 379.95 & 569.93 & 759.91 & 0.18 & 0.36 & 0.54 & 0.73 \\
\hline 84 & Nuclear reactors, boilers, mchy & $72,068.754$ & 0.01 & 0.11 & 0.22 & 0.32 & 0.43 & 0.00 & 0.00 & 0.00 & 0.00 \\
\hline 52 & Cotton. & $67,440.708$ & 4.74 & 87.91 & 175.82 & 263.73 & 351.64 & 0.13 & 0.26 & 0.39 & 0.52 \\
\hline \multirow[t]{2}{*}{72} & Iron and steel. & $37,321.414$ & 4.85 & 54.30 & 108.61 & 162.91 & 217.21 & 0.15 & 0.29 & 0.44 & 0.58 \\
\hline & All Commodities & $2,481,606.235$ & 2.12 & 1841.35 & 3682.70 & 5524.06 & 7365.41 & 0.07 & 0.15 & 0.22 & 0.30 \\
\hline
\end{tabular}

Scenario I = 25 per cent tariff cut, Scenario II = 50 per cent tariff cut, Scenario III = 75 per cent tariff cut \& Scenario IV = 100 per cent tariff cut (i.e. free trade)

* Simulations are based on gravity model. Methodology is spelt out in the text. 
Table 7 :Likely increase in Japan's exports to India under different PTAs and FTA, 2005* (value in US '000\$)

\begin{tabular}{|c|c|c|c|c|c|c|c|c|c|c|c|}
\hline \multirow[b]{2}{*}{$\begin{array}{l}\text { HS } \\
\text { Code }\end{array}$} & \multirow[b]{2}{*}{ Name of the Commodities } & \multirow[b]{2}{*}{$\begin{array}{c}\text { Japan's exports } \\
\text { to India (2005) } \\
\text { '000 \$ }\end{array}$} & \multirow[b]{2}{*}{$\begin{array}{l}\text { MFN Tariffs } \\
\text { of India } \\
\text { (Wtd.Avg) }\end{array}$} & \multicolumn{4}{|c|}{ Increase in Exports (Value in '000 US \$) } & \multicolumn{4}{|c|}{ Percentage Increase } \\
\hline & & & & Scen.I & Scen.ll & Scen.III & Scen.IV & Scen.I & Scen.II & Scen.III & Scen.IV \\
\hline 84 & $\begin{array}{l}\text { Nuclear reactors, boilers, } \\
\text { mchy \& m }\end{array}$ & $1,099,474.437$ & 14.26 & 3919.626368 & 7839.253 & 11758.88 & 15678.51 & 0.36 & 0.71 & 1.07 & 1.43 \\
\hline 85 & $\begin{array}{l}\text { Electrical mchy equip parts } \\
\text { thereof }\end{array}$ & $410,811.980$ & 9.33 & 2108.081675 & 4216.163 & 6324.245 & 8432.327 & 0.51 & 1.03 & 1.54 & 2.05 \\
\hline 87 & Vehicles o/t railw/tramw roll-stock & $405,091.575$ & 37.96 & 384.4319047 & 768.8638 & 1153.296 & 1537.728 & 0.09 & 0.19 & 0.28 & 0.38 \\
\hline 72 & Iron and steel & $247,401.974$ & 20 & 1237.00987 & 2474.02 & 3711.03 & 4948.039 & 0.50 & 1.00 & 1.50 & 2.00 \\
\hline 90 & $\begin{array}{l}\text { Optical, photo, cine, meas, } \\
\text { checkin }\end{array}$ & $217,915.158$ & 12.96 & 1765.11278 & 3530.226 & 5295.338 & 7060.451 & 0.81 & 1.62 & 2.43 & 3.24 \\
\hline 29 & Organic chemicals & $217,204.571$ & 14.48 & 1493.933039 & 2987.866 & 4481.799 & 5975.732 & 0.69 & 1.38 & 2.06 & 2.75 \\
\hline 39 & Plastics and articles thereof & $125,251.240$ & 15 & 939.3843 & 1878.769 & 2818.153 & 3757.537 & 0.75 & 1.50 & 2.25 & 3.00 \\
\hline 73 & Articles of iron or steel & $115,313.592$ & 15 & 302.698179 & 605.3964 & 908.0945 & 1210.793 & 0.26 & 0.53 & 0.79 & 1.05 \\
\hline 37 & $\begin{array}{l}\text { Photographic or cinematographic } \\
\text { goo }\end{array}$ & $75,071.353$ & 15 & 281.5175738 & 563.0351 & 844.5527 & 1126.07 & 0.38 & 0.75 & 1.13 & 1.50 \\
\hline \multirow[t]{2}{*}{40} & Rubber and articles thereof & $67,575.039$ & 14.83 & 50.10689142 & 100.2138 & 150.3207 & 200.4276 & 0.07 & 0.15 & 0.22 & 0.30 \\
\hline & All Commodities & $3,439,909.518$ & 15.36 & 21134.80408 & 42269.61 & 63404.41 & 84539.22 & 0.61 & 1.23 & 1.84 & 2.46 \\
\hline
\end{tabular}

Scenario I = 25 per cent tariff cut, Scenario II = 50 per cent tariff cut, Scenario III = 75 per cent tariff cut \& Scenario IV = 100 per cent tariff cut (i.e. free trade)

* Simulations are based on gravity model. Methodology is spelt out in the text. 
The simulation results show that the most significant increase in Japanese exports to the Indian market will be in HS category 90 i.e., optical, photographic, cinematographic, measuring and checking machineries. Due to FTA, under the cetris paribus assumption, Japan's total exports to India in this category would increase by 3.24 per cent followed by plastics and articles of plastics, where exports will increase by 3 per cent. Other commodity groups, which will register significant increase in exports are: electrical machinery, equipments and parts (HS 85) with a rate of growth of exports of 2.05 per cent; organic chemicals (HS 29), with 2.75 per cent; machinery and machine tools (HS 84) with 1.43 per cent rise; iron and steel (HS 72) with 2 per cent; and goods in (HS 37) with an export growth of 1.5 per cent.

Thus, the overall results in Tables 6 and 7 indicate that due to FTA, Japan's exports to the Indian market will increase by 2.46 per cent compared to only 0.3 per cent increase in India's exports to the Japanese market. The present study has only considered the reduction and then complete elimination of tariffs. Obviously, India will be the loser in the short run. Any amount of tariff reduction in the Indian market will significantly increase Japanese exports because of higher tariffs in India. PTAs and FTA will be meaningful only when the agreement addresses the bound tariffs of both the countries. Since Japan's tariff is much low, its bound tariff is also very low. On the other hand, in the Indian context, the base level tariff is very high, therefore, bound tariffs is equally high. Thus, if bound tariff is not addressed with the current reduction of tariffs and if it is not based on the latest tariff reduction, any preferential and free trade arrangement is bound to be futile.

\section{VI : Concluding Remarks}

The new regionalism of the 90's, unlike the trading arrangements of the 60's, has member countries with (a) vastly different levels of development, (b) different sizes of population, (c) different levels of domestic economies, and structure of production, and (d) varying degrees of openness. The Proposed India-Japan FTA is expected to provide a basic ground for strengthening and widening economic cooperation between two big countries of the Asian region. Trade cooperation will further extend to other areas of economic cooperation viz. cooperation in investment and joint ventures, cooperation in services trade and cooperation in harmonization of international rules and regulations of standards and certification procedures. This study shows that only tariff-based approach won't be effective in improving intraregional trade since tariff level in Japan is already very low and India has been reducing tariffs over the years. It is unfortunate that India's tariff rate is still amongst the highest in the world and its bound tariffs are set at exorbitantly high level. There is indication that base level will be fixed at the current level of the prevailing rate in near future. In order to pursue FTA much vigorously, India has to sacrifice much more than any country in terms of rationalizing its tariff structure and make it compatible with its trading partners. Tariff based approach wont' yield any desired results at least in the short run for India. Rather, it will lose its market to its competitors, whose tariff regimes are low.

Though Japan's tariff level is not much higher than that of India, it's NTB-coverage and frequency ratios are exorbitantly high compared to its trading partners. Japan has much stringent SPS and TBT standards than most other countries in the world. Though under Article 3.3 of SPS rule of WTO, every country can pursue its own national standard and certification system independently, under the veil of this rule, most of the developed countries including Japan using this tool as a NTB in protecting 
its imports of agricultural goods. Japan is yet to make any reform in its agricultural sector and its agricultural market is heavily protected through tariff rate quota (TRQ) and other NTBs. Liberalization of agricultural market should be an integral part of any FTA negotiations in future. Though about 40 per cent of Japan's imports are duty free, but the rate is quite high in labour intensive low value added items, such as garment and textiles, in which India has substantial interests. Entire exercise will be futile until agricultural sector is brought under the ambit of FTA along with the investment measures.

As the gravity model does not take into account the possible impact of the terms of trade associated with the trade creation, the simulated results are generally upward biased. The estimates also give the results in a static framework, and the extent of intraregional trade will possibly further increase if the estimation is carried out in a dynamic framework, incorporating the effects of factors like terms of trade, scale economies, technology spill-over, investment inflows, and trade liberalization. These could reinforce the short-term trade creation, thus underestimating the true long-run impact. Due to lack of basic information to quantify the above cited variables, the estimation of the parameters related to these factors becomes difficult. For example, some price elasticities could be approximated, but information on scale economies do not exist. However, a number of existing studies have shown that the short-term impact is higher than the dynamic impact. The results in this paper do not take into consideration the concessions offered in the form of non-tariff barriers; it only considers reduction of tariffs under different scenarios, which is purely hypothetical. The results of alternate scenarios have also not measured the effect of PTAs/FTAs on different variables related to welfare. Even if the simulations undertaken here correctly measure the impact on trade creation, it should be realized that this impact is not the only factor to be taken into account in evaluating FTAs. The negative effect on bilateral trade with countries not entering in the simulated arrangement is not assessed in these simulations. Therefore, none of the indicators from the simulations could be viewed as a welfare measure, thus making the comparison of different scenarios incomplete. The results of the simulations presented here serve the limited purpose of providing an estimate of the potential effects on bilateral trade between India and Japan in the simulated PTAs. Nevertheless, this paper has demonstrated how the conventional gravity model can be modified in terms of modeling and estimation to examine the impact of 'behind the border' constraints for a given level of 'implicit beyond the border' constraints on bi-lateral exports.

Besides the PTAs and FTA, the analysis in this study highlights the importance of eliminating 'behind the border' constraints that prevail within home country. The existing levels of 'behind the border' constraints both in India and in Japan indicates that bi-lateral trade flows with their partner countries can be increased substantially by removing their respective 'behind the border' constraints. Unless these trade restricting factors are not eliminated, the benefits from PTAs and FTA cannot be fully realized between countries. While moving towards this objective, countries will experience many other complicated problems faced by other agreements. First of all, "rules of origin" principle is to be well defined to arrest re-routing cheaper imports from different countries. Minimum value-addition norms should be strictly adhered to. Given the already existing regional agreements in operation in this region, this is bound to result a "spaghetti bowl" type of phenomenon, where for a given product, there could be several and different tariff rates depending on what origin is assigned 
to it. Second problem is the harmonization of standards and uniform certification procedures between India and Japan. The SPS and TBT are most stringent NTBs affecting the prospects of Indian agricultural exports to the Japanese market. The third problem is the identification of negative list of commodities of the respective countries and a detail plan to prune it in a phased manner and to prepare comprehendsive national schedules of items to be offered for concessions among the members.

This study shows that the major beneficiary of FTA between Japan and India will be Japan because of its lowest tariffs in the region. In the short run, India's gains from free trade are considered to be much less because of its higher tariffs compared to that of Japan. When India gives duty free access to Japan, tariff revenue previously collected on the imports from Japan turns into export revenues for the exporting firms of Japan, which is obviously very high because of higher levels of tariffs in India. In this process, Japanese firms will gain more compared to Indian exporters because of lower tariffs in the former country. Due to less or non-existing tariffs in the Japanese market, exporting firms of India have less to gain, at least in the short run, from the tariff free access to Japan. Conversely, when Japan gives duty free access to the exporters of India, tariff revenue previously collected from the imports from India turns into export revenues for the exporting firms of the latter country, which will be obviously very low because of lower tariffs in Japan.

The above description is the direct effect of free trade arrangements between Japan and India. Most of these effects are valid in the short run only. But as a second best solution, apart from the declining tariff revenues for India, it can gain substantially in some other ways. Increase in duty free imports from Japan might translate into at least partial reduction in consumer prices in India. Such reduction in consumer prices will be much higher compared to reduction in consumer prices in Japan for imports from India. Therefore, welfare gains of Indian consumers will be higher than the welfare gains of the Japanese consumers. Nevertheless, as long as India continues to have higher tariffs than Japan, the danger of potential losses from the transfer of tariff revenue to the Japanese firms in the form of higher profits will remain. As Panagarya has suggested, while thinking of FTA between two countries, one having higher tariff and the other lower tariff, it should be on a non-discriminatory basis first, and tariff levels of the high-tariff country should be brought down to the level of the low tariff country. Therefore, to extract maximum benefits from the free trade arrangements between Japan and India, it is desirable that the latter should bring down its tariff level to that of former country, if not in the short run, but in the long run.

Finally, the formation of Japan-India FTA is a part of a bigger exercise in the Asian region, which has been undergoing for quite sometime. The ultimate objective of trade liberalisation and trade integration of this region is to integrate the entire Asian economies. At present, there are 49 major sub regional and bilateral trade and cooperation agreements in the Asian region of 47 countries. ASEAN has already formed a free trade union with PTA in vogue. Since India and China are two big emerging markets in the Asian region, it has been mooted for quite sometimes to bring Korea, China, Japan and India into its fold to form a bigger and stronger JACIK (Japan-ASIAN-China-India- Korea) economic group. China has been playing a leading role in all FTAs in the Asian region. ASEAN and four dialogue partners viz. Japan, Korea, China and India (JACIJ) are all actively engaged in evolving the FTAs between the pairs. Through the complex web of FTA negotiations, it is expected that JACIK may be a reality, if not in the short run and must be in the long run. 


\section{References}

Aigner, D., Livell, K.C.A., and Schmidt, P. 1977. Formulation and Estimation of Stochastic Frontier Production Function Models. Journal of Econometrics, 6: 21-37

Anderson, James E., 1979. "A Theoretical Foundation for the Gravity equation." American Economic Review, 69(1): 106-116 (March).

Anderson, James E., and Eric van Wincoop, 2003. "Gravity with Gravitas: A Solution to the Border Puzzle “. American Economic Review, 93(1): 170-192 (March).

Baldwin, Richard., 1995. "A Domino Theory of Regionalism.” In Expanding Membership of the European Union," Richard Baldwin, Pentti Haaparanta, and Jaakko Klander (eds). New York: Cambridge University Press.

Baldwin, R. and Taglioni, D. (2006). 'Gravity for Dummies and Dummies for Gravity Equations', NBER Working Paper No. W12516.

Barro, R., and Sala-I-Martin, X.1995. Economic Growth. New York: McGraw-Hill

Bergstren, C. Fred, 1996 "Competitive Liberalization and Global Free Trade: A Vision for the Early $21^{\text {st }}$ Century ." Washington, D.C: Institute for International Economics, Working Paper 96-15

Bhagwati, Jagdish, and Arvind Panagarya, 1999, "Preferential Trading Areas and Multilateralism." In Trading Blocs, Jagdish Bhagwati, Pravin Krishna, and Arvind Panagarys (eds). Cambridge, MA: MIT Press.

Coelli, T. 1996. A Guide to FRONTIER Version 4.1: A Computer Program for Stochastic Frontier Production and Cost Function Estimation, Centre for Efficiency and Productivity Analysis Working paper 97/07, University or New England, Armidale

Deardorff, A. 1995. 'Determinats of Bilateral Trade: Does Gravity Work in a Neoclassical World?' NBER working Papers No. 5377.

Dhar, S., and Panagariya, A. 1996. "Is East Asia Less Open than North America and the EEC? No". Paper presented at the International Economics Association Round Table Conference in International Trade Policy and the Pacific Rim, Sydney, July 15-17.

Drysdale, P. and Garnaut, R. 1982. "Trade Intensities and the Analysis of Bilateral Trade Flows in a Many-country World: A Survey", Hitotsubashi Journal of Economics, 22(2): 62-84.

Elizondom, R.L., and Krugman, P. 1992. 'Trade Policy and Third World Metropolis'. NBER Working paper No. 4238. Washington, DC: National Bureau of economic Research.

Estevaleordal, Antoni, 2006. "The Rise of R egionalism." Paper presented in the Conference, "The New Regionalism: Progress, Setbacks and Challenges" held at the InterAmerican Development Bank, Washington, DC, February 9-10, 2006.

Frankel, JA., 1993. "Is Japan Creating a Yen Bloc in the East Asia and the Pacific?," in J.A.Frankel and M.Kahler (eds) Regionalism and Rivalry: Japan and the United States in Ppacific Asia. Chicago: University of Chicago Press.

Gawande, K., and Krishna, P. 2001. The Political Economy of Trade Policy: Empirical Approaches. Working papers, Economics Department. Providence, RI: Brown University.

Geraci, V.J., and W. Prewo., 1977. "Bilateral Trade Flows and Transport Costs." Review of Economic Statistics, 59, 67-74

Kalirajan, K. 1999, Stochastic Varying Coefficients Gravity Model: An Application in Trade Analysis. Journal of Applied Statistics, 26: 185-194

Kalirajan K. (2007), "Regional Cooperation and Bilateral Trade Flows: An Empirical Measurement of resistance." The International Trade Journal, 21(2), (Summer).

Krugman, P., "The Move Toward Free Trade Zones." In Policy Implications of Trade and Currency Zones, Federal Reserve Bank of Kansas, Jackson Hole, Wyoming, August.

Levchenko, A.A. 2004. Institutional Quality and International Trade. IMF Working paper, WP/04/23. Washington, DC: IMF

Linnemann, H., 1966. An Econometric Study of International Trade Flows. Amsterdam: North Holland Publishing. 
Matyas, L., 1997. "Proper Econometric Specification of the Gravity Model". World Economy, 20: $363-368$

Meeusen.W., and van den Broeck ,J., 1977. Efficiency Estimation from Cobb Douglas Production Function with Composed Error. International Economic Review, 18: 435444

Newfarmer, Richard and Dorota, A Nowak (2005). 'The World Bank in Trade: The New Trade Agenda' in Richard Newfarmer (ed.) Trade, Doha, and Development: A Window into the Issues, The World Bank, Washington, D.C.

Roemer, J.E., 1977."The Effect of Sphere of Influence and Economic Distance on the Commodity Composition of Trade in Manufactures". The Review of Economics and Statistics, 59: 318-327

Rodrik, D., 2000. Trade Policy as Institutional Reform. Cambridge, MA: Harvard University, Department of Economics.

Rodrik, D., 1998. "Why Do More Open Countries Have Large Governments?" Journal of Political Economy 106 (5): 758-879

Schumacher. D., Perspektiven des Aufenhandels zwischen West-und Osteuropa: Ein disaggregierter Gravitationsatz, Deutsches Institut fur Wirtschaftsforschung, Berlin, February 1997.

Silva, S.J.M.C., and Tenreyro, S. 2003. "Gravity-Defying Trade". Working Papers 03-1: Boston: Federal Reserve Bank of Boston

Tinbergen, J., 1962. "Shaping the World Economy: Suggestions for an International Economic Policy". New York: The Twentieth Century Fund.

Wacziarg, R. 1997. Trade, Competition and market Size. Cambridge, MA: Harvard University, Department of Economics.

Wilson, J.S., Mann, C.L., and Otsuki, T. 2004. "The Potential Benefit of Trade Facilitation : A Global Perspective". World Bank Policy Research Working Paper 3224, February. Washington, DC: The World Bank 